\title{
Hledání další inspirace
}

Stalo se zvykem připisovat jakékoliv neobvyklé stavy mysli nějakým vyšším, nejspíše duchovním zdrojům. Nicméně i bez nábožného, nebo dokonce náboženského zápalu prožívá řada $\mathrm{z}$ nás $\mathrm{v}$ běžném životě okamžiky, kdy se $\mathrm{z}$ ničeho nic a bez předchozího přemýšlení objeví na první pohled nijak nemotivované, nereflektované porozumění realitě. Jakési náhlé vhledy, dalo by se říci opatrným jazykem vědecké psychologie, př́ípadně pod dojmem objevů současných kognitivních neurověd. Společně s našimi předky ale můžeme podobné jevy přičíst rovněž na vrub blíže nespecifikované intuici, která se vyznačuje právě tím, že se něco přihodí neočekávaně, byt částečně tušeně. Poznání či jasné prozření přichází jakoby shůry, přičemž podežrení na vyšší síly pak lze už jen stěží odolat. Intuitivní nazření totiž umožňuje překročit hranice, zároveň však zachovat niterné přesvědčení o vlastní cestě. Jako kdyby se uvolněná hra asociací nějakým rozumem přímo neuchopitelným způsobem prolínala s logikou možných kombinací. Nicméně připomeňme, že od průkopnických časů Sigmunda Freuda se snění s vědecky laděnou analýzou nijak nevylučuje.

Z této perspektivy stojí za pozornost postoje a výroky všestranného teoretika Ivana M. Havla obratně se pohybujícího v „zákulisích“ lidské psychiky. V rozhovoru s Petrem Fischerem tento kybernetik, kognitivní vědec a znalec umělé inteligence a robotiky uvažoval takto: „Intuice je schopnost přijmout nápad a okamžitě ho nezavrhnout, i kdyby byl na první pohled šílený. K tomu je třeba jakéhosi ,osvícení - nejen abychom nápad přijali, ale abychom ho navíc opravdu vzali vážně“ [Fischer - Havel 2019: 71]. Své úvahy dále rozvinul o nic méně pozoruhodným dodatkem: „Pak je tu ovšem ještě něco dalšího: organizační schopnost. Většina těch, kdo mají intuici a vezmou něco vážně, nakonec přece jen skončí špatně, protože s tím nejsou schopni dál nic dělat, nedovedou nikoho strhnout a přitáhnout k nápadu další lidi."

V této souvislosti hovoří o vizionářství, které si nepředstavuje jako kolektivní vlastnost. Soudí, že tu nejprve musí být jednotlivec, solitér, někdo odvážný. Podobně jestliže dnešní vědec nebo jakýkoliv jiný nekonvenční myslitel chce nové vize realizovat, potřebuje pomoc ostatních, nehledě na nepředvídatelné propojení štěstí, náhody a technologicky zralé situace. Ivan M. Havel v citovaném rozhovoru trefně pojmenovává taktéž podstatnou sílu „nápadu“: „Vždycky je u toho nějaký vpád něčeho nového do běžného stavu věcí. Běžný stav věcí je nakonec takový nudný. Ale když do něj vpadne nějaký nápad, může se něco velkého stát“" [Fischer - Havel 2019: 73].

Nyní již pravděpodobně nikoho ze čtenářů nepřekvapí, že Ivan M. Havel se ve své mnohostranné tvorbě i v rámci vlastní osobní filozofie zabývá zdánlivě vědecky tak odlehlým tématem, jako je oblast „snové práce“. Hned v úvodu své „snově specifické“ publikace poznamenává následující věty: „Stále častěji se mi stává, že mne během dne nečekaně a nechtěně přepadne mikrospánek. Dochází k tomu např́iklad při sledování přednášky 
nebo filmu (méně často při čtení knihy), a kupodivu to nesouvisí s tím, zda přednáška, film, či kniha je nudná či naopak vzrušující. Mikrospánek je zpravidla neobyčejně krátký, stačí však na to, aby se přede mnou na okamžik objevil nějaký výjev, který je zcela mimo můj vliv a bez jakékoliv souvislosti s bdělým světem. Jakmile se proberu, jsem překvapen, že jsem chvilku nejen dř́mal, ale i snil“ [Havel 2018: 9].

Ukazuje se, že bdělý stav může být přerušen neobyčejně krátkým mikrospánkem. $\mathrm{V}$ př́slušné literatuře se odhaduje jeho trvání na méně než 30 sekund. Okamžitě se přítom objevují mikrosny, jimž je „snové já“ přítomno jako divák. Lze tedy hovořit o jakési aktérské pozici, z čehož vedle sociologických a antropologických zřetelů vyplývá i možnost založení neuropsychologie mikrosnění, respektive psychoanalýzy mikrosnů. Dalšími Havlovými klíčovými slovy otevírajícími pro snění různé badatelské oblasti jsou „introspekce“ a "prožitek“" popř́ípadě „perzistence“ (stálost, vytrvalost až tvrdošíjnost snu nebo jeho částí). Neobejdeme se ani bez pojmu „retence“ čili zadržení, protože psychologicky vzato schopnost připomenout si dřívější zážitky při opakujících se nebo podobných vnějších podnětech a situacích se stává podmínkou pro práci s nimi. Nikoliv jen pro zajímavost uvedme, že Havlova „sbírka“ čítá 239 záznamů snů, což už je slušná porce interpretačního materiálu...

Sám Ivan M. Havel [2018: 106] podává na základě dlouholeté zkušenosti s vlastním sněním a mikrosněním toto shrnutí: „Jak vidno, i zdánlivě úzké zážitky otevírají celé zkušenostní pole. Konkrétní probuzení z mikrospánku není jen událostí přechodu mezi snem a bděním, ale i př́spěvkem k obecné zkušenosti, že s pocitem reality to není jen tak. I mžikový pohled z verandy se podílí na zkušenosti, že ani s hranicí mezi viděným a neviděným to není jen tak. Pohled introspektora pak zvlášt zřetelně ukazuje, že, a jak, je možno si uvědomit své vlastní Já a jeho vztah ke zkušenostnímu poli: že zkušenost je situovaná, adresná a Já se k ní pevně váže, vyvstávajíc spolu s ní a ve vztahu k ní.“

Dalo by se tímto vzrušujícím směrem jistě uvažovat dále, avšak z editorialu se nemůže vyklubat samozvaná recenze, nebo snad letmo nahozená studie. Přesto nás mohou stávající „snové úvahy“ přivést $\mathrm{k}$ určitým závěrům, především $\mathrm{k}$ důrazu na význam improvizace, jejíž výsledky nemusí být hned perfektní. Potřebujeme se zkrátka přinejmenším čas od času dostávat do proudu mimořádných a nepředvídatelných štastných náhod či shod okolností, vykročit jaksi „mimo rámec“. Metaforicky řečeno běží o tzv. serendipitu, tedy zvláštní „polohu mysli“, štastnou náhodu“ nebo „př́ijemné překvapení (takto se s tímto termínem setkáváme např́íklad u spisovatele Horace Walpola). Pojem pochází ze sanskrtu a zaznívá třeba v Pohádkách tisíce a jedné noci. V minulosti byl jeho ekvivalentem v češtině výraz „serepetička“. V sociologii hovořil o principu serendepity jako o určitém heuristickém př́stupu Robert K. Merton. Dokonce i badatelské marginálie a omyly (viz objev penicilinu) nás mohou dotlačit k velkému průlomu. Lze namítnout, že to všechno zní až př́liš jako rajská hudba sny omámené mysli, popřípadě coby pouhé zbožné přání, a tak raději po tomto náročném expozé vstupme přímo do hájemství historické sociologie.

Historičtí sociologové se vyznačují zvýšenou citlivostí k otázce plynutí času. Nedávno jsme si připomínali deset let od založení našeho časopisu a studijního programu na Fakultě humanitních studií Univerzity Karlovy [Narbut 2019], a nyní vstupujeme již do druhého desetiletí. Každý posun, jako je tento, vyvolává reflexe na téma kontinuity a diskontinuity. 
Tím, kdo nás v v březnu tohoto roku opustil, je Johann (Joop) Goudsblom, holandský badatel, kterého jsme měli možnost přivítat v Praze v prosinci 2004, když v Sociologickém ústavu AV přednesl přednášku na téma svého slavného knižního díla Fire and Civilization. Ke Goudsblomovu jménu neodmyslitelně patři podpora a šíření idejí Norberta Eliase [Šubrt 2014: 166], sociologie dlouhodobých historických procesů a sociálních figurací, kterým se dlouhodobě věnoval v Amsterdamu v rámci Nadace Norberta Eliase a jejího newsletteru Figurations.

Osobností, která se zasloužila o rozvoj historické sociologie v Praze i v celosvětovém měřítku, je Jóhann Páll Árnason (nar. 1940), který v tomto roce oslavuje své životní jubileum. „Náš Jóhann“ se mimo jiné výtečné vlastnosti vyznačuje trvalou nápaditostí a velkým zájmem o naše oborové periodikum. Jubilantovi jsme proto v interview položili pár otázek, které měly směřovat k objasnění jeho historicko-sociologického stanoviska. Ostatně v blízkém výhledu lze pod jeho taktovkou očekávat „japonské číslo“ Historické sociologie. Přichází též s nápadem, aby jedno z dalších vydání časopisu pokrylo téma jak historikové vidí sociologii. Určitě by k této problematice měli co říci významní badatelé v historiografii Zdeněk Beneš, Miloš Havelka, Jan Horský, Miroslav Hroch, Michal Kopeček, Jan Rychlík, popř́ípadě další. Poté by následovala kolektivní odpověd' historických sociologů na názory a návrhy oslovených kolegů historiků.

Ještě než se k něčemu takovému odhodláme, je potřeba přednostně vzít v potaz nové trendy v sociologii vůbec a v historické zvláště. A tak součástí „jedničky“ Historické sociologie tohoto roku se stala i studie Jany Kadlecové věnovaná fenoménu „body-hacking“, vlastně různým technologickým modifikacím těla. Ukazuje se, že klasický článek Marcela Mausse o technikách těla $\mathrm{z}$ roku 1935 bezpochyby potřebuje další doplňky. Od devadesátých let minulého století, kdy se „body-hacking“ objevil jako ojedinělý druh undergroundových extrémních modifikací, se totiž ledacos změnilo. Původně se jednalo o vývoj „zdola“, hlavně DIY přístup spjatý s experimenty i značným rizikem. Právě „body-hacking“ představuje relativně nový trend v tělesných modifikacích, zahrnující vývoj, produkci a užívání různých technologických implantátů mimo oblast oficiálního zdravotnictví. V neposlední řadě je tento fenomén autorkou zasazen do problematiky kybertělesnosti, fyzických a symbolických proměn lidského těla, katalyzovaných kybernetickými a digitálními technologiemi.

Podotýkám dále, že se v rámci tohoto interdisciplinárního periodika trochu náhodně vytvořil a „vynořil“ blok ke konceptu kapitalismu v historickém průřezu. Čtveřice autorů, konkrétně Zdeněk Nebřenský, Svatopluk Herc, Tomáš Gecko a Jakub Štofánik, objasňuje konceptuální základy a projevy manufaktury, welfare kapitalismu neboli „kapitalismu blahobytu“, „paternalisme industriel“ apod. Za povšimnutí stojí např́íklad, že koncept welfare kapitalismu, který se poprvé objevil ve Spojených státech amerických, pojednal výstižně Svatopluk Herc s ohledem na to, jak se uplatňuje i jako synonymum pro sociální stát a tomu odpovídající způsob vlády. Ovšem samotná definice má dvě stránky - na jedné straně adjektivum „welfare“ původně patří do sféry soukromého sektoru, z druhé strany pak jde o úkol státu zajistit patřičnou životní úroveň pro všechny (welfare state). Herc si mimo jiné klade za cíl objasnit, jak welfare kapitalismus uspěl v řešení sociální otázky a dokdy vlastně trval.

Dlouhodobý výzkumný grant NAKI ke studiu automobilismu, řízený Janem Štemberkem, má v našem časopise už své stálé místo, například v podobě prezentace dílčích položek projektu nebo recenzí. V tomto čísle Miroslav Sabol nastínil „trampoty“ prvních 
motoristických nadšenců při objevování turistických atrakcí na Slovensku. Na vysvětlenou připomeňme, že v rámci první etapy tohoto projektu jsou v letech 2018-2020 zkoumány společenské aspekty automobilismu v českých zemích. Jeden z rozsáhlejších výstupů byl v lednu tohoto roku publikován v kolektivní monografii České století motorismu I. Kulturní roviny českého motorismu (Bohuslav Šalanda - Jan Štemberk a kol.) v nakladatelství Karolinum. Ostatně zmíněný Jan Štemberk v periodiku Historická sociologie uveřejnil v roce 2013 zásadní studii „Cestovní ruch a česká společnost na přelomu 19. a 20. století“.

Rád bych ještě upozornil alespoň na glosu Marka Německého, která ve výstižné zkratce představuje dílo Immanuela Wallersteina (1930-2019). V minulém čísle našeho časopisu bylo avizováno, že této významné osobnosti bude postupně věnována patřičná pozornost. Nebudu tu tedy předčasně rekapitulovat jeho koncepci světových dějin v perspektivě „světového systému“ ani komplexní teorii vzniku a fungování kapitalismu, jakož i další Wallersteinův přínos pro sociální a humanitní vědy.

Závěrem těžko rozhodnout, zda čtenářum tohoto čísla Historické sociologie, at už konzumovaného $\mathrm{v}$ papírové nebo elektronické podobě, přát výše zmiňovaný mikrospánek, nebo dokonce delší, sny naplněné spánkové spočinutí. Záleželo by totiž výhradně na tom, $z d a$ řečené nastalo $v$ tom lepším případě pod vlivem inspirace, $v$ horším pak jako důsledek myšlenkové únavy. Věřme raději v inspiraci a jí probuzenou intuici, která na čtenářské straně povede k zachování věrnosti Historické sociologii a na straně autorské zavelí k tvorbě podnětných příspěvků do dalších čísel našeho žurnálu. Prozatím se ponořme do probírání přítomného svazku.

Bohuslav Šalanda

DOI: $10.14712 / 23363525.2020 .1$

\section{Literatura}

Ajvaz, Michal - Havel, Ivan M. [2008]. Snování. Rok dopisů ve snech. Červený Kostelec: Pavel Mervart.

Fischer, Petr - Havel, Ivan M. [2019]. Vizionáři jsou otevřeni podivnostem. Magazín deníku E15, roč. 3, říjen, s. 69-74.

Lukeš, Jan [2017]. „Právě proto, že jsem. “ Rozhovor s Ivanem M. Havlem. Praha: Knihovna Václava Havla. Havel, Ivan M. [2018]. Zápisky introspektora. Praha: OIKOMENH.

Narbut, Nikolay P. [2019]. Ten years of historical sociology in Prague: A new perspective branch of Czech sociology. RUDN Journal of Sociology (1): 167-174.

Stachová, Jiřina - Nosek, Jiří [1993]. Intuice ve vědě a filozofii (Sborník př́íspěvků). Praha: Filozofický ústav ČSAV.

Šalanda, Bohuslav - Štemberk, Jan a kol. [2019]. České století motorismu I. Kulturní roviny českého motorismu. Praha: Karolinum.

Štemberk, Jan [2019]. Cestovní ruch a česká společnost na přelomu 19. a 20. století. Historická sociologie (1): 75-88.

Šubrt, Jiří [2014]. From the Past to the Present and towards Possible Futures: The Collected Works of Norbert Elias (Zpráva o konferenci). Historická sociologie (1): 165-166. 